This work was carried out during the tenure of a Pig Industry Development Authority postgraduate scholarship. I thank Dr. T. Gillman for encouragement and helpful suggestions, and Miss Anne Dain for her assistance.

Department of Experimental Pathology,

A.R.C. Institute of Animal Physiology,

Babraham, Cambridge.

Received January 24, 1967.

' Kim, Y. B., Bradley, S. G., and Watson, D. W., Fed. Proc., 23, 346 (1964).

${ }^{2}$ Kim, Y. B., Bradley, S. G., and Watson, D. W., J. Immunol., 97, 52 (1966).

${ }^{3}$ Weide, K. D., Sanger, V. L., and Lagrace, A., J. Amer. Vet. Med. Assoc., 141, 464 (1962).

4 Aiken, J. M., and Blore, I. C., Amer. J. Vet. Res., 25, 1134 (1964).

s Kelly, D. F., J. Comp. Path., 74, 381 (1964).

6 Segre, D., and Kaeberle, M. L., J. Immunol., 89, 790 (1962).

iterzl, J., Kostka, J., Mandel, L., Riha, I., and Holub, M., in Mechanism of Antibody Formation, 130 (Publ. House Czechoslov. Acad. Sci., 1960).

"Pestana, C., Hallenbeck, G. A., and Shorter, R. G., J. Surg. Res., 5, 306 (1965)

${ }^{9}$ Miller, J. F. A. P., Brit. Med. Bull.,22, 21 (1966).

"Good, R. A., and Papermaster, B. W.. Adv. in Immunol., 4, 1 (1964).

${ }^{\prime \prime}$ Binns, R. M., and Hall, J. G., Brit. J. Exp. Path., 47, 275 (1986).

${ }^{12}$ Silverstein, A. M., Thorbecke, G. J., Kraner, K. L., and Lukes, R. J., $J$. Immunol. 91,384 (1963).

${ }^{13}$ Billingham, R. E., and Brent, L., Phil. Trans. Roy. Soc., B, 242, 439 (1959).

\section{Blood Groups of Baboons demonstrated with Isoimmune Sera}

SIMIAN-TYPE blood groups of non-human primates were first demonstrated by isoimmunization in chimpanzees and gibbons $^{1,2}$. Since the original reports, ten distinct chim. panzee blood factors have been described belonging to four blood group systems ${ }^{3}$ and additional blood factors are under investigation.

In view of the increased use of baboons in experimental research ${ }^{4-7}$, it appeared of interest to investigate the simian-type blood factors of this primate species. Our initial attempts (in collaboration with $\mathrm{J}$. Haglin) to produce antisera by immunizing rabbits with baboon red cells yielded inconclusive results, because the non-specific immune heteroagglutinins interfered and could not easily be absorbed. Isoimmunization experiments were therefore initiated. This communication describes the results of the first successful isoimmunization experiments.

Four baboons (Papio cynocephalus) were isoimmunized by injecting $1 \mathrm{ml}$. of whole blood mixed with an equal amount of complete Freund's adjuvant by the intra. muscular route. Two such injections were given at intervals of 6 weeks. Two of the four baboons responded by producing isoantibodies, which could be demonstrated weakly even after the first injection.

As shown in Table 1, the two isoantibodies produced differ in specificity. They have therefore been assigned the distinctive symbols anti- $\mathbf{A}^{\mathrm{P}}$ and anti- $\mathbf{B}^{\mathrm{P}}$, respectively, where the superscript " $\mathrm{P}$ " stands for "Papio". Both antisera have similar serological properties, in that they react weakly by the saline agglutination method, do not agglutinate ficinated red cells, and produce best reactions by the antiglobulin method, by which method both had similar titres of approximately 16 units.

Table 1. RESULTS OF ISOIMMUNIZATION OF FOUR BABOONS

\begin{tabular}{|c|c|c|c|c|c|c|}
\hline Immunized & Donor & & \multicolumn{4}{|c|}{ Reaction of serum with } \\
\hline $\begin{array}{l}\text { baboon } \\
\text { No. }\end{array}$ & $\begin{array}{l}\text { baboon } \\
\text { No. }\end{array}$ & $\begin{array}{l}\text { Antibody } \\
\text { produced }\end{array}$ & No. 2 & $\begin{array}{l}\text { ed cells } \\
\text { No. } 9\end{array}$ & $\begin{array}{l}\text { f baboor } \\
\text { No. } 11\end{array}$ & No. 13 \\
\hline No. 2 & No. 11 & Anti-A $\mathbf{A}^{\mathrm{P}}$ & - & + & + & - \\
\hline No. 9 & No. 13 & Anti-B $\mathbf{B}^{\mathrm{P}}$ & & - & - & + \\
\hline No. 11 & No. 2 & None & - & - & - & - \\
\hline No. 13 & No. 9 & None & - & - & - & - \\
\hline
\end{tabular}

In our work on simian-type blood groups of chimpanzees and gibbons, anti-human globulin rabbit sera were used for the antiglobulin test, that is, reagents prepared for testing human blood which had been further absorbed with

* To avoid ambiguity, symbols for blood factors and their corresponding antibodies are printed in bold type, and symbols for agglutinogens, phenotypes and blood group systems are printed in roman type. red cells of these apes. The same antiglobulin reagents showed some reactions in tests with the isoimmune baboon sera; the reactions were not sharp, however, and antibaboon globulin sera were therefore prepared and used in the present experiments.

Tests with anti-AP and anti-BP isoimmune sera were carried out on a series of thirty-three baboons (Papio cynocephalus). All four of the theoretically possible types of red cell were found. As shown in Table 2, despite the small size of the series, a definite association is evident between the two blood factors $\mathbf{A}^{\mathbf{P}}$ and $\mathbf{B}^{\mathrm{P}}$. This supports the impression, derived from their similar serological behaviour, that they belong to the same blood group system. This system, which may be designated the simiantype A-B system of baboons, is probably the counterpart of the human M-N-S system and the chimpanzee V-A-B system $^{8}$, judging from the failure of the antibodies to react with ficinated red cells.

Table 2. DISTRIBUTION OF THE $\mathbf{A}^{\mathrm{P}}-\mathbf{B}^{\mathrm{P}}$ BLOOD TYPES AMONG THIRTY-EIGHT BABOONS (Papio cllnocephalus)

$\begin{array}{cc}\text { Simian-type blood groups* } & \text { ro. of animals } \\ \text { O } & 12 \\ \text { A } & 8 \\ \text { B } & 3 \\ \text { AB } & 10\end{array}$

* As distinguished from the human-type" A-B-O blood groups.

Isoimmunization experiments on larger series of baboons are being pursued to prepare a panel of antisera of different specificities.

We thank Mr. Bruce McPherson and Mr. Hugh Binley for help with the immunization and bleeding of the animals, and Miss Pat Ryan, Mrs. Dina Santana, Miss Sybil Gordon, and Miss Toby Steckel for help with the laboratory tests. The work was assisted by the use of the facilities of Hofstra University, Hempstead. Long Island, and wholly supported by grants from the U.S. Public Health Service.

Department of Forensic Medicine.

\section{J. MOOR-JANKowSKI}

Alexander S. Wiener

Eve B. GORDON

Office of the Chief Medical Examiner of New York City and Department of Forensic Medicine.

Joseph H. Davis

Department of Forensic Medicine,

New York University School of Medicine,

New York.

Received December 19, 1966.

${ }^{1}$ Moor-Jankowski, J., Wiener, A. S., and Rogers, (. M., Science, 145. 1441 (1964).

2 Moor-Jankowski, J., and Wiener, A. S., Nature, 205, 369 (1965). Moor-Jankowski, J., Wiener, A. S., Kratochvil, C. H., and Fineg, J., Intern.
Arch. Allergy, 29, 397 (1966).

${ }^{4}$ Haglin, J., Telander, R. I., Muzzal, R. E., Kiser, J. C., and Strobel, (. J., Surg. Forum, 14, 196 (1963).

${ }^{5}$ Hitcheock, C. R., Minnesota Med., 47, 1213 (1964).

- Goldsmith, E. I., and Kean, B. H., Gastroenterology, 50, 805 (1966).

" Goldsmith, E. I., Carvalho Luz, F. F., Prata, A., and Kean, B. H., J. Amer. Med. Assoc. (in the press).

${ }^{8}$ Wiener, A. S., Moor-Jankowski, J., and Gordon, E. B., Exp. Med. Surg.. 23, 256 (1965).

9. Moor-Jankowski, J., Wiener, A. S., and Rogers, C. M., Nature, 202. 663 (1964).

\section{Effects of Extracts from Thymus on Homograft Survival in Rats}

Numerous investigators have reported the effects of neonatal thymectomy on immunological responses ${ }^{1-4}$. Immunological competence has been restored by implanting thymic grafts ${ }^{1}$, by inserting a cell tight chamber containing thymus into the intraperitoneal cavity of the thymectomized animal ${ }^{5,6}$ by injecting whole cells from spleen or thymus ${ }^{7}$ and by injecting a cell frec extract of thymus ${ }^{8}$. None of these methods provided unequivocal 